\title{
Cosmopolitanism and Oscillation in Orhan Pamuk's My Name is Red
}

\author{
Catharina Brameswari \\ catharinabrameswari@usd.ac.id \\ English Letters Department, Universitas Sanata Dharma
}

\begin{abstract}
This research emphasizes on the challenges stemming from the attempts in inventing Turkey's new ideal identity faced by the miniaturists in Orhan Pamuk's My Name is Red. It focuses on the encounter and tension between the East and the West that is symbolized in the usage of the Italian Renaissance painting style by Turkish miniature painters. There are two issues discussed namely the EastWest oscillation and the complex desire to imitate others. The miniaturists face the predicament in the development of Turkey's new ideal identity, which is represented in the appropriation of the Italian Renaissance Painting. I employed library research which borrowed Said's discourse on Orientalism and Bhabha's Postcolonialism in order to dismantle the endless oscillation in My Name is Red. Through his work, Pamuk wants to emphasize his position for not taking sides. Additionally, he tries to raise his critic to Turkey's abrupt modernization and suggests hybridity as the solution to the predicament of the East-West oscillation.
\end{abstract}

Article

information

Received:

29 January, 2020

Revised:

30 April 2020

Accepted:

25 May 2020:

Keywords: cosmopolitanism; oscillation; liminality; hybridity

DOI: 10.24071/joll.v20i2.2392

Available at https://e-journal.usd.ac.id/index.php/JOLL/index

This work is licensed under a Creative Commons Attribution-ShareAlike 4.0 International License.

\section{Introduction}

Turkey's cultures are mix of Eastern and Western culture and traditions because of its special location. This cosmopolitanism is challenged by the oscillation to embrace the East or the West which results in the ambivalence of identity. On the other hand, it is also as the result of the radical modernization that is forced by the elite colonizer (read: the Kemalist). Eder (2001) explains that the "Westernisation" had destroyed 600-year Islamic Ottoman Empire tradition and made Turkey a secular country, which was the valuable price as the consequence of Turkey's membership in the
European Union. Additionally, Ataturk transformed the religion-based former Ottoman Empire into a modern nation with a separation of state and religion, such as the restriction of veils in parliament and school, the alteration alphabet from Arabic in the Turkish language into Latin, and the banned of Turkish traditional drink, Boza.

The East-West encounter, the seduction of Western culture, as well as the desire to become and imitate the Other have led Turkey to this high tension. Turkey also experiences the ups and downs emotion of anxiety to embrace the forced modernity and the feeling of hüzün because of the loss of the Ottoman's 
past glory. Hüzün is the shared feeling of melancholy which brings power and hopes to the Turks. A melancholy feeling when the citizens are trapped between two worlds. Based on the issues mentioned above, this research tries to discuss two issues namely the oscillation of the East and the West and the complex desire to imitate others.

The desire and longing to Westernize Turkey and the dilemma of the Ottoman Turks who are searching for their identity in the influence of Western values have been captured by Orhan Pamuk into My Name is Red (MNR). Pamuk captured this feeling through the history of miniature painters in the Ottoman miniature guild, which is filled by conflict, jealousy, and murder among the painters. In this novel, Pamuk tries to criticise both the Modernists and the Traditionalists who insist that Turkey should have only one single soul. On the other hand, Pamuk also gives space and appreciates the process of an individual who is looking for his identity without any claims from the others, which can distract him from his identity formation processes. Pamuk (2008) underlines that "it is not a big problem for Turkey to have two different cultures and spirits and they should not worry about it because it is not a bad thing" (p. 369). From the quotation above, it can be seen that he suggests us to embrace different cultures and encourages us to invent new cultures. Pamuk also wants to remind his readers that Turkish forced modernization project had only left a big scar. In his masterpiece, My Name is Red, Pamuk captures the feeling that dominates the city and displays melancholy for the loss of the old traditional miniature painting.

This study aims to reveal how modernity-which is represented by the Italian Renaissance art-has challenged the Turk's life, tradition, culture, art, and identity. My Name is Red has all aspects, which can sharpen the readers' awareness on the seduction of modernity. The European tradition can disrupt their culture and traditions and also lead to identity crisis-or even lose it. Through this story, we can learn that the Turks have orientalised themselvesin other words: Orientalism by the orientalby feeling inferior to the art they make for they believe that the West can bring them to modernity.

Furthermore, this study is also conducted with the hope to raise the reader's awareness regarding to the identity degradation as a result of the rendezvous between the EastWest traditions. I hope that the Indonesian readers can filter the Western traditions and choose which one is suitable to their custom, belief, and culture so that they can still maintain and hold their tradition and identity as Indonesian. It is for the reason that, nowadays, I still find many young generations who are reluctant to deal with the valuable Indonesian culture and traditions which have high value. Conversely, they prefer to have, use, or consume Western or American products and perform their traditions. My vision through this research is that young generations will embrace modernity without leaving their tradition and identity as Indonesian.

\section{Methodology}

In this research, I mainly employ the method of library research. There are two kinds of sources that are used; they are primary and secondary sources. The method applies in conducting the study is qualitative approach. Additionally, the primary source is a novel written by Orhan Pamuk, a Turkish novelist, entitled My Name is Red (2001). To support the primary data, the secondary data are taken from books, Pamuk's non-fictions: Istanbul: Memories of the City (2006) and Other Colours (2008), journals, articles, criticisms, interviews, book review, and videos discussing and analysing Orhan Pamuk and his literary works. The data, then, are analysed to discover the connection between the socio-culture and historical condition and the events portrayed in both novels.

The research is conducted in several steps. The first step of this study is to find the topic to be discussed. The second step is to select the literary works that are going to be analysed. The third step is the technical reading of the novels as the fundamental step before turning to further analysis. After formulating the problems related to the topic, finding the secondary sources and the 
appropriate approach are employed in the analysis. The next step is answering the formulated problems. Here, I attempt to apply the theories on Orientalism from Said and Post-colonialism from Bhabha, reviews, and criticism from the secondary sources to analyse the primary sources. At last, I conclude the important points of analysis as the result of analysis and give some suggestions to future researchers who want to analyse My Name is Red.

\section{Literature Review}

Orhan Pamuk, the winner of the Nobel Prize in Literature, tries to bring back the story of Ottoman past through his tales. Batur (2007) adds that the past, as he tells his tales, becomes more like a creative puzzle in the pages of My Name is Red (p. 9). His work usually invites various scholarly discussions and debates. However, this research focuses especially on the dialogue and negotiation between the East and the West, the high tension between the enchanting art and Ottoman traditions, as well as the identity formation process toward a new expected ideal identity.

The first research is by Feride Çiçekoglu (2001), titled "A Pedagogy of Two Ways of Seeing: A Confrontation of 'Word and Image' in My Name is Red", which claims that My Name is Red is a narrative of the clash between two perspectives. It is about the tale of how the Frankish painting disturbs and challenges the Islamic miniature tradition and its miniaturists. In addition, this article attempts to pick up clues in the oeuvre for tracing two different ways of seeing EastWest framework in the late $16^{\text {th }}$ century, not as a binary opposition, but as a dialectical trope of word and image.

Orhan Pamuk's oeuvre also invites some Indonesian scholars to discuss it. One of the researchers is Albertus Bagus Laksana. His article entitled "İstanbul: Melankoli yang Mendera" (2013) explores the concept of hüzün in Pamuk's Ístanbul: Memories and the City and My Name is Red as a deep spiritual loss towards past's glory and a fear to face the future. Here, Laksana states that the entire İstanbul resident as well as the characters in
My Name is Red, cannot freed the complexity of hüzün from their spiritual and cultural experience. However, he also finds a solution to overcome the complexity of hüzün by combining and living in the two traditionsthe East and the West tradition (Laksana, 2013, pp. 28-35).

Moreover, to analyse My Name is Red, this study will employ Edward Said's discourse on Orientalism and Homi K. Bhabha's hybridity, in-betweenness, mimicry, and ambivalence. Those theories help the writer to uncover the predicament of the oscillation between the East and the West. In addition, those also unearth the solutions to overcome the problems which are offered by Pamuk's story. Additionally, postcolonial theory is also borrowed to deconstruct the complex and ambiguous desire to imitate others, which is mainly on Turkish characters in My Name is Red.

Bhabha (1994) criticises colonial discourse by proposing the concept of mimicry. He explains that mimicry is one of the most elusive and effective strategies of colonial power and knowledge (p. 85). Lacan reminds us that the effect of mimicry is camouflage (Bhabha, 1994, pp. 120-121). The imitation of the colonizer does not mean that the colonized imitates the colonizer identically. Bhabha (1994), adapts Weber's formulation, explains this idea:

colonial mimicry is the desire for a reformed, recognisable Other, as a subject of difference that is "almost the same, but not quite". The discourse of mimicry is constructed around "ambivalence" because mimicry stays on two different conditions. In order to be effective, mimicry must continually produce its slippage, its excess, its difference, for mimicry is a sign of a double articulation, which "appropriates" the Other as it visualises power (p. 86).

In line with Bhabha, Lou (2011) stresses that Mimicry lives and exists on the binary opposition; the colonizer and the colonized, or the Self and the Other (p. 1). Bhabha (1994) highlights that desire to be "authentic" through the appropriation of the colonizer is 
the final irony of partial representation (p. 88). Through imitating the colonizer, the colonized tries to rewrite his identity in the liminal space by becoming hybrid (p. 120).

Ashcroft (2007) mentions that generally, Hybridity simply means cross-cultural "exchange". In post-colonial discourse, this term used many times to underline its idea in expressions of syncreticity, cultural synergy, and transculturation (p. 109). In addition, Bhabha (1994) adds that Hybridity is the resistance of colonial power domination. This "almost the same but no quite" is a weapon to mock the existence of the colonizer. He presents hybridity as a tool to fight against the colonizer when the "uncivilized" culture enters the dominant discourse (p. 114). Conversely, Pamuk tries to give a new colour to hybridity in his My Name is Red. He uses hybridity as a room to think about and repress the ambivalence. In the context of Turkey, the forced national identity has led the oscillation to embrace the East or the West. Based on this, Pamuk insists that the Turks should choose their identity freely whether they want to be secularists, Islamists, or even mix.

\section{Identity Formation Process}

Identity is fluid. It is never fixed and it always changes. Other culture, tradition, art, or even modern technology will always challenge and influence an identity. Turkey is still searching for its "authentic" identity, whether being totally East, being totally West, being nationalist or secularist, or being hybrid. Turkey is now still writing their new identity above their Islamic Ottoman identity that is still visible even though it had already destroyed by the Westernization project. The changes of Istanbul are the evident on how the Turks try to acquire their identity by imitating others.

Istanbul is a model of "palimpsest that its history cannot be swept clean like a blackboard so that the people might inscribe their own future there" (Said, 2003, p. xii). Ataturk's Westernization project has abruptly erased a city full of grandeur as well as harmonious multiple cultures, ethnic, and religion of the Ottoman Empire. This can be seen from the changes of the old Istanbul buildings. The new modern apartment buildings replaced the buildings which were demolished by the government. It illustrates and shows how the new Turkish identity is overwritten above the old Ottoman identity. However, it is ironic because the old identity is still visible under the newer one since there are still the old Ottoman buildings and ruins that remain (Pamuk, 2006).

Turkey past important figures, Mehmed II, Atik Sinan, and Murad III, and the miniature painters in My Name is Red experience a predicament and the identity crisis which is still gnawing on. Even though Mehmed II had conquered Constantinople, he still wanted to be the West by way of inviting an Italian painter to paint him in the manner of the Italian Renaissance painting. Jardine and Brotton (2000) mention that Mehmed invited Gentile Bellini to create "the Portrait of Mehmet II" (p. 8). The appropriation of European point of view by the Ottoman leader shows Turkey's desire to be the West and the influence on its "new turn toward Europe". They add that his interest to Christianity as well as Western culture and tradition was because of his mother's influence (p. 32). The young sultan-who was still twenty-four years old when he captured Byzantiumalways wanted to know and understand the latest developments in art. In the 15th century, the also invited artists from Florence and Venice produced medals and paintings for the Ottoman Sultan (Çiçekoglu, 2001, p. 4).

Though Mehmed II had an interest in Western culture, but he also tried to challenge the masterpiece of the Byzantine Empire. According to Stierlin (2002) the Ottomans construct a mosque called The Fatih Camii (the Mosque of the Conqueror) after capturing Constantinople. The mosque was built on the site of the ruined Byzantine church of the Holy Apostles in order to substitute the grand of Christian Byzantium buildings (pp. 100-101). The Fatih chose a Christian architect, Christodoulos, or better known under his Turkish name of Atik Sinan (Sinan the Elder). The Ottoman's daily contact with the Byzantine masterpieces and the architect's background who was a Christian converted to Islam, had strongly influenced 
the architecture of the mosque (Kuiper, 2010, pp. 200-206). Additionally, Sinan's design is the evidence that Hagia Sophia (Western heritage) has given big influence to the mosque.

The contested identity and the oscillation in Turkey's identity formation processes become Pamuk's key colours in "painting" his stories. Pamuk also blends the capitulation of the Byzantine city, the collapse of the Ottoman Empire, and the nostalgia of Istanbul's multicultural past with the issue about Turkey's contested identity to present the oscillation between Self and Other in $M y$ Name is Red. Borrowing from Said's viewpoint (2003), Pamuk delineates how "the Other is always presented as a threat and seduction". Farred (2007) also reveals that the fundamental issue in his tales is on the matter of identity (pp. 88-89). Pamuk (2006) declares that we can only find our true identity by imitating others. He narrates that when he still wanted to become a painter, Utrillo had affected his style of painting. In addition, he stresses that by imitating Utrillo he could have his own style and identity (pp. 270-271). It is along with the way Pamuk and Islamic miniature painters find their true identity by using or imitating Utrillo and the Frankish style of painting.

Pamuk, in My Name is Red, presents the oscillation between Self and Other. He delineates how the Other is always presented as a threat and seduction. Pamuk illustrates the oscillation by showing how the miniaturists embrace and imitate the Italian Renaissance style as well as the sultan who are eager to pose in the manner of the Frankish masters. By contrast, the miniaturists are also afraid if the Frankish painting leads to the loss of the old painting style. Uncle Effendi states that the love all sultans and rulers feel for paintings, illustrations, and fine books can be divided into three points:

at first, the Ottoman Sultans want paintings for the sake of respect and to influence how others see them. ...On the second point, they commission books to satisfy their own taste because they have learned to enjoy paintings..., while at the same time amassing books, which after their deaths, and ensure the persistence of their renown in this world. ...At last, they have a conclusion that painting is an obstacle to securing a place in the Otherworld, naturally something they all desire, because painting is believed as an act of blasphemy (MNR, 175).

The quotation above shows how the Italian painting not only works as a seduction but also as a threat and obstacle for the sultan and even for the miniaturists to enter the gates of Heaven..."for Our Prophet warns that on Judgement Day, Allah will punish...painters and those who make idols" $(M N R, 175)$.

Shekure, Enishte's daughter, is also still searching for her true identity. She experiences the oscillation between her contempt of the Frankish painting her father admires at and her longing to be painted in a manner of that painting style. Shekure is both "fed up with those illustrations her father was having the miniaturists make in imitation of the Frankish masters and sick of his recollections of Venice" (MNR, 152). In the end of the story, she secretly has a desire to have her own portrait in the manner of the Italian Renaissance style. She stresses that she would be very happy in her old age if she had a youthful portrayal of herself $(M N R, 443)$. Her statement indicates how the Frankish style seduces her but in the same place also threatens her family safety. This can be seen when the miniaturists' murderer comes into her house and kills his father.

Turkey's identity formation processes are like completing the puzzle, which part can be filled and which identity can be written only by referring or mirroring to the Other. Pamuk suggests the third space to his readers as a room to mirror the Other. This place can be employed to reflect Turkey's new identity. The liminal space is a space to negotiate the everlasting predicament of the oscillation between the East and the West. This room is also a place where someone can use it to give birth to hybridity. Moreover, it can also be used as a bridge that connects the two poles and as an alternative solution of this predicament. What is more important here is 
that anything happen in the third space should be enjoyed and celebrated.

\section{Impartiality}

As a novelist, Pamuk does not choose nor judge one of the sides explicitly. As it is stated in the quotation above, Pamuk wants to be a bridge that does not belong to any sides as well as connects both sides and mediates the predicament of the oscillation. He appreciates the process of an individual who is looking for his identity without any claims, which can distract him from his identity formation process. Along with the argument above, Iyer (2007) underlines that Pamuk refuses to settle into one position, which made him the target of both secularists and religious conservatives. Additionally, Pamuk (2008) also insists that "it is not a big problem for Turkey to have two different cultures and spirits" (p. 369) for he claims that imitating the West or the Ottoman culture is not the solution (p. 370). Through his works, Pamuk criticises Kemal Atatürk's secular agenda which want to simplify and purify the complex cosmopolitanism by erasing all Turkey's Ottoman tradition and banishing otherness.

Iyer (2007) states that as a consequence of Pamuk's refusal and critique to both sides in his oeuvres, he becomes the target of both secularists and religious conservatives. Those groups claim that "Turkey should have only one consistent soul" (Pamuk, 2008, p. 369). Moreover, Pamuk's statement (2008) regarding to the Atatürk's modernization project which mentions the massacre of thirty thousand Kurds and a million Armenians has pushed a wave of protest to against him (pp. $237,356)$. In addition, after using the word "genocide" to describe the massacre, Pamuk was brought to prison for three years for publicly denigrated Turkish identity and provoking public outcry in Turkey (Özel, 2007, p. 18).

Pamuk (2008) states that My Name is Red is shaped from the mixture of East-West methods, styles, habits, and histories (p. 264). Instead of giving any clear solutions to the oscillation in his oeuvre, Pamuk stresses how the representatives of both traditions experience tragedy and death in their lives. The murderer in MNR has two victims, Elegant Effendi, who first opens the story as a corpse, and Enishte Effendi, the man behind the Sultan's secret book. Erdağ Göknar (2004), the translator of My Name is Red, explains in "My Name is Re(a)d" that Olivethe painters' murderer-both loves and hates the Frankish style. He kills Elegant Effendi, a gilder who is also the follower of the great preacher Nusret Hoja of Erzurum, for being overly interested in Islamic painting style and because Elegant claims Olives' aesthetic as blasphemous (p. 54). The murderer is afraid if the group of Islamic fundamentalist hears that the miniaturists paint forbidden pictures $(M N R, 424)$, nothing will remain even the book-arts workshop $(M N R, 23)$.

Similarly, Master Osman-the representative of Eastern tradition and the head of the Ottoman miniaturist-blinds himself using the needle used by Master Bihzad to blind himself $(M N R, 348)$. This is as a way Master Osman used to fight for the Italian painting style. Moreover, his decision to blind himself is because of his disappointment towards his miniaturists who leave the old tradition and imitate the Frankish style. Two years after blinding himself, Master Osman died and Stork replaces his position as the Head Illuminator $(M N R, 443)$. In addition, Olive's reason to murder Enishte Effendi is because he is being too slavish to Western innovation. Enishte's visit to Venice has made him enchanted by the Venetian painting and it drives him to influence the sovereign to be painted by Sebastiano in this manner. His motivation for killing Enishte Effendi arouses because he knows that the modern painting style will naturally replaces the old Islamic painting due to the political and social conditions (Göknar, 2004, p. 54). This is in line with Enishte's statement on the day Olive kills him that the paintings made by the miniaturists will be easily forgotten and replaced by the new method of painting.

However, the loss of the Islamic painting "was simply because Western ways of seeing and painting were more attractive" (Pamuk, 2008, p. 270). Kantar (2007) mentions that in the future, "the Eastern world will lost" ( $p$. 
131) for every painter will paint in Western style and leave the illumination painting. However, we cannot avoid this because the Western ruling elite wants to modernize Turkey by replacing the 250-year-Persian painting. Olive, the murderer, is also experience a tragedy and death in his life. His miniaturist colleagues blind him. Additionally, when Olive is on his way to Galleon Harbour to flee to India, Hasan attacks and kills him for accusing him as one of the raiders who comes his house at night to kidnap Shekure (MNR, 435). He cuts Olive's head in a single stroke by using his red sword (MNR, 439).

Olive murder's series shows the EastWest binary opposition. Göknar (2004) mentions that the moment Hasan kills Olive illustrates the binary opposition of body and mind, tenor and vehicle, content and form, and even East and West (p. 55). In the end of his life, Olive still describes the scene that he sees from ground level. In this moment of observation, he realizes that seeing has become a variety of memory $(M N R, 436)$. In Venetian painting, seeing (perspective) is very important because an object is depicted realistically. While in Persian painting, "a miniaturist's 'eyes' are at the tip of his pen and acting before he can think; his hand is acting of his own accord" (Pamuk, 2006, p. 150).

Furthermore, Pamuk's impartiality can be seen more in $M N R$, which contains the leitmotif of a failed or "missing" book or manuscript (Göknar, 2006, p. 37). In My Name is Red, Olive, as the miniaturist who represents Western tradition, will do anything to bring the Ottoman art to modernity. Sultan's commissioned book, moreover, cannot be finished for Olive murders Elegant Effendi, the gilder. He kills Elegant because he is afraid that Elegant can put the book in danger by spreading rumours to the followers of Nusret Huja that the book contains blasphemy. Besides, he also steals the unfinished book from Enishte Effendi after hits Enishte's head using a bronze Mongol inkpot in order to keep the sustainability of the Islamic painting tradition that is contested by the Renaissance style of painting $(M N R, 191)$.
After finding the last painting, Olive tries to complete the manuscript by presenting his self-portrait. In the end, he fails to make his own portrait, no matter how hard he tries. "Imitating the Frankish masters, as Olive explains, needs certain expertise and the proficiency of the Franks will take centuries to attain. Besides, if the miniaturists still attempt to attain a style and European character, they will still fail" (MNR, 431). Nevertheless, Olive's failure in imitating the Italian Renaissance style can be one of his ways to fight against the domination of this painting style. His strategy is in the same vein with Bhabha's theory (1998) on almost the same but not quite that the colonized tries to resist the colonizer by imitating their culture, but not totally and precisely, which aims to mock them. This is also similar to Gandhi's thought on "Caliban paradigm" that the colonized learns how to curse in the master's tongue (p. 148).

Pamuk shows Turkey's imitation and inauthenticity through Olive's self-portrait in the secret book and his statement made to his dear friends. Olive warns the miniaturists that if they yield to the Frankish painting they might resemble themselves but they will not be themselves. On the other hand, if the painters of the old tradition are still faithful to the old masters they will lose their place as a palace miniaturist $(M N R, 420)$. From Olive's statement above, Pamuk (2008), once again, wants to remind us that "slavishly imitating the West or slavishly imitating the old dead Ottoman culture is not the solution" (p. 370). Pamuk also asks us to live in both cultures and/or to produce a new culture from the combination of those cultures. However, the radical and abrupt modernization that is forced by the elite lead to the ambivalence of identity for a person lives between two identities that alienate him to his true identity.

Both Pamuk and Bhabha have similar idea on the concept of hybridity. They highlight that everything is hybrid, we are all hybrid, whether it is from our name or language. In his masterpiece, Pamuk reminds us that "nothing is pure" $(M N R, 176)$ in this world. Along with what Bhabha emphasizes that hybridity, principally, shows that the 
culture of a nation is the result of the interaction between nations, groups, or ethnics of a nation. Through My Name is Red, Pamuk asks his readers to respect the multiculturalism and cosmopolitanism around them. In addition, he also invites us to be critical and to deconstruct the postmodern movement of the fundamentalists as well as the nationalists who want to purify and simplify the complexity of the multiculturalism in Turkey.

\section{Conclusion}

In My Name is Red, Pamuk stunningly captures and paints Turkey's desire to westernize itself and its dilemma whether to preserve their old Ottoman tradition or to totally embrace the modernity. The encounter of the Ottoman Empire and the West has created a desire to appropriate Western art, culture, and technology that are seductive. $M y$ Name is Red tries to capture the endless oscillation around the two traditions, between the miniature painting and the Italian Renaissance painting.

However, Pamuk also shows that the Other (the West) is not only present as a seduction towards the Turks, but also as a threat to their tradition. This threat, in addition, has encouraged Master Osman, Nusret Hoja and his follower, as well as Olive to take action to preserve their traditions. Furthermore, the predicament of the oscillation between being enchanted to the West and being drawn to its own tradition that Turkish society is undergoing has led to the identity crisis that is experienced by Pamuk's characters and also the Ottoman Sultans.

Pamuk's My Name is Red discusses and deconstructs the issue on the identity formation as well as a criticism to the ruling leader of their countries. Through his brilliant works, Pamuk wants to deliver a message to his readers that being a schizophrenic by embracing two identities is fine. Embracing Western tradition without leaving our national identity and local culture is not a big sin. He also invites us not to leave and forget the past, but keep reminding it and keep it as well as use it as a lesson so that we can be a better nation. He uses Ottoman history to look at and criticise the future. Through his masterpiece, we are invited to appreciate, respect, and maintain the diversity of cultures, traditions, and religions around us that, nowadays, it seems difficult to be realized. My Name is Red has all aspects, which can sharpen the readers' awareness on the enchantment of modernity that challenges the multiculturalism or even disrupts their culture and traditions as well as leads to the identity crisis.

Additionally, through this novel-which is the mixing of two traditions, styles, and histories-Pamuk tries to create the liminal space and to mediate the predicament of the oscillation between the East and the West as well as to bridge the in-betweenness. The Sultan's commissioned book is Pamuk's alternative solution that he offers toward Turkey's predicament of the oscillation. Pamuk tries to mediate the complex oscillation as well as release hüzün felt by the Ottoman miniaturists by harmonizing the two contradict ways of seeing in the hybrid book.

\section{References}

Ashcroft, Bill, et.al. (2007). Post-Colonial Studies. New York: Routledge.

Batur, Pinar. (2007). Author in the Classroom: An Interview with Orhan Pamuk. Middle East Studies Association Bulletin, 41(1), 9.

Bhabha, Homi. K. (1994). The Location of Culture. London: Routledge. 85-86, 88, $114,120-121$

Çiçekoglu, Feride. (2001). A Pedagogy of Two Ways of Seeing: A Confrontation of 'Word and Image' in My Name is Red. Journal of Aesthetic Education, 37(3), 4.

Eder, Richard. (2001, September 2). Heresies of the Paintbrush. New York Times. Retrieved May 20, 2013 from <https://www.nytimes.com/2001/09/0 
2/books/heresies-of-thepaintbrush.html>.

Farred, Grant. (2007). To Dig a Well with a Needle: Orhan Pamuk's Poem of Comparative Globalization. The Global South, 1(2).

Göknar, Erdağ. (2004). My Name is Re(a)d: Authoring Translation, Translating Authority. Translation Review, 68, 54.

(2006). Orhan Pamuk and the 'Ottoman' Theme. World Literature Today, 80(6), 37.

Iyer, Pico. (2007, September 30). A View of the Bosporus. New York Times. Retrieved November 6, 2013 from: < https://www.nytimes.com/2007/09/30/ books/review/iyer.html>.

Jardine, Lisa \& Brotton, Jerry. (2000). Global Interests: Renaissance Art between East and West. London: Reaktion Books Ltd.

Kantar, Dilek. (2007). The Stylistic Dialogue of East and West in Orhan Pamuk's The White Castle. Challenging the Boundaries. Amsterdam: Rodopi B. V.
Kuiper, Kathleen. (2010). Islamic: Art, Literature, and Culture. New York: Britannica Educational Publishing.

Laksana, Albertus Bagus. (2013). İstanbul: Melankoli yang Mendera. BASIS, 62(1-2), 28-35.

Lou, Cherry. (2011). Mimicry and Its Discontents: Examining Bhabha's Multiculturalism as Mimicry and Hibridity. Student Pulse, 3(10), 1.

Özel, Soli. (2007). Turkey Faces West. The Wilson Quarterly, 31(1), 18.

Pamuk, Orhan. (2001). My Name is Red (Benim Adim Karmizi). London: Faber \& Faber. trans. E. M. Göknar.

. (2006). Istanbul: Memories and the City, New York: Vintage International. trans. Maureen Freely.

. (2008). Other Colours: Writing on Life, Art, Books, and Cities. London: Faber and Faber Limited. trans. Maureen Freely.

Said, Edward. (2003). Orientalism. London: Penguin Books, Ltd.

Stierlin, Henri. (2002). Turkey: from the Selçuks to the Ottomans. Köln: Taschen. 